\title{
Biochemical profiling and its role in physiological quality of maize seeds ${ }^{1}$
}

\author{
Daniele Nerling ${ }^{2}$, Cileide Maria Medeiros Coelho ${ }^{3 *}$, Adriele Brümmer ${ }^{3}$
}

\begin{abstract}
Viability and vigor of seeds are physiological attributes influenced by a myriad of factors including the genotype. Biochemical profiling of maize seeds and its correlation with their physiological quality is of crucial importance in breeding programs that the aim is seeds of better quality. The main goal of this study was to analyze the genetic diversity among maize inbred lines and evaluate the biochemical components that have an important role in physiological quality of seeds. The seeds of the inbred lines and hybrids were submitted to viability test, vigor by the accelerated aging and cold tolerance, and biochemical profiling (total protein content, soluble proteins, total phosphorus, phytate, inorganic phosphorus, starch and soluble sugars). The genetic divergence between the inbred lines found, prompt us to conclude that genetic gains may exist in association with physiological quality of maize hybrids. Seeds with higher inorganic phosphorus and soluble sugars presented superior physiological quality than seeds with lower levels of those compounds.
\end{abstract}

Index terms: vigor, viability, genetic divergence, stored reserves, Zea mays.

\section{Perfil bioquímico e seu papel na qualidade fisiológica de sementes de milho}

\begin{abstract}
RESUMO - A viabilidade e o vigor de sementes são atributos fisiológicos influenciados por uma série de fatores, incluindo o genótipo. O perfil bioquímico das sementes de milho e sua correlação com a qualidade fisiológica são importantes para programas de melhoamento que objetivam obter sementes de melhor qualidade. O objetivo deste estudo foi analisar a diversidade genética entre as linhagens de milho e avaliar os componentes bioquímicos que têm um papel importante na qualidade fisiológica das sementes. As sementes das linhagens e dos híbridos foram submetidas ao teste de viabilidade, vigor pelo envelhecimento acelerado e tolerância ao frio e a determinação do perfil bioquímico (teor de proteína total, proteínas solúveis, fósforo total, fitato, fósforo inorgânico, amido e açúcares solúveis). A divergência genética encontrada entre as linhagens permite concluir que os ganhos genéticos podem existir em associação com a qualidade fisiológica dos híbridos de milho. As sementes com maior teor de fósforo inorgânico e açúcares solúveis apresentaram qualidade fisiológica superior à das sementes com níveis menores desses compostos.
\end{abstract}

Termos para indexação: vigor, viabilidade, divergência genética, reservas armazenadas, Zea mays.

\section{Introduction}

Seeds represent the basis for successful food production in the agriculture and quality attributes are of important significance for this success. Among the attributes of seed quality, viability and vigor play an important role. The use of seeds with high vigor determines its potential for rapid, uniform emergence and development under a wide range of field conditions (Ventura et al., 2012; Rajjou et al., 2012). The establishment and growth of seedlings has been claimed to be initially supported by

${ }^{1}$ Submitted on 11/28/2016. Accepted on 10/30/2017.

${ }^{2}$ Departamento de Fitotecnia, Universidade Federal de Santa Catarina, 88034-001 - Florianópolis, SC, Brasil. the hydrolysis and conversion of stored reserves, proteins, carbohydrates and lipids (Bewley et al., 2013).

Environmental conditions prevailing during seed formation and agricultural practices (fertilization and sowing dates) may cause changes in the chemical composition of the seeds. Thus, variations can be observed depending on the species, variety, flowering physiology, nutrition and environmental conditions (Marcos-Filho, 2005). These factors can interfere the ability of seeds to germinate under different environmental conditions, and moreover, the

${ }^{3}$ Laboratório de Análise de Sementes, Universidade Estadual de Santa Catarina, 88520-000 - Lages, SC, Brasil.

${ }^{*}$ Corresponding author <cileide.souza@udesc.br> 
genotype influence genetic and biochemical processes, associated with germination and vigor (He et al., 2014). Seeds with greater vigor have more reserves of proteins, lipids, and carbohydrates. These findings may be related to the fact that high vigorous seeds have a higher starch content, soluble proteins and sugars, and greater capacity to mobilize reserves during the germination period (Henning et al., 2010; Kim et al., 2011). Seed vigor has been claimed to be related to different pathways such as those involving sulfur aminoacids, lipid and starch mobilization and protein synthesis. Proteins are important as their provide seeds with metabolic capacity to overcome cellular damage during stress conditions and are also involved in the control of germination (Rajjou et al. 2012). Carbohydrates (i.e., starch, sucrose, raffinose, stachyose, verbascose), are involved with the provision of respiratory substrate, integrity of membranes, viscosity of the cytoplasm and other processes that interfere with germination and seed vigor (Bernal-Lugo and Leopold, 1995).

Although significant advances involving the study of the biochemical composition associated with germination and vigor, have been made, studies relating the genetic characteristic that affect seed physiological quality are scarce in the literature. The identification of superior genotypes with better physiological quality is important in a breeding program, since these characteristics are genetically inherited from the parents (Santos et al., 2012).

In other hand, studies involving biochemical profiling requires data integration from different sources and differentiated statistical interpretation, with the use of appropriate statistical models that consider the complexities of these processes. In this sense, the use of supervised statistical methods, such as partial least squares regression (PLSR), has become an important tool in the study of biological processes (Varmuza and Filzmoser, 2009). This method allows making a relationship between biochemical composition with viability and vigor of seeds. The objective of the study was to analyze the genetic divergence between the inbred lines and evaluate the role of biochemical components in the physiological quality of maize seeds.

\section{Material and Methods}

Five inbred lines of maize in the fifth generation of selfpollination, hereinafter designed as CRI, VPA1, VPA2, HIB1 and HIB2, were used in this study. The CRI inbred line was obtained from a landrace, VPA1 and VPA2 were obtained from commercial open-pollinated varieties and HIB1 and HIB2 inbred lines, obtained from single hybrids. Initially, the seed multiplication of inbred lines was conducted in season
2014/2015 in São Miguel do Oeste, Santa Catarina State (Brazil). Concurrently, hybrid combinations were also obtained through artificial pollination of plants $(1 \times 3,1 \times 4,1 \times 5,2 \times$ $1,3 \times 1,4 \times 1,4 \times 2$ and $5 \times 2$ ). The first number indicated in the hybrid combination refers to the inbred line used as male parent. The number of hybrid combination refers to the inbred lines used as parents: number 1 refer to CRI inbred line, 2 refer to VPA1, 3 refer to VPA2, 4 refer to HIB1 and 5 refer to HIB2 inbred line. The maize ears were collected manually when seeds reached approximately $18 \%$ of moisture content. After that the maize ears were threshed, seeds dried in the shade until they reach $13 \%$ of moisture and stored in cold chamber with relative humidity of $50 \%$ and $12{ }^{\circ} \mathrm{C}$ temperature.

The physiological quality of seeds was evaluated by the germination test, cold tolerance, and accelerated aging test. The germination test consisted of four subsamples of 50 seeds and was conducted according to Brasil (2009). The accelerated aging test was conducted, using four replications of 50 seeds each. Seeds were distributed on aluminum screens fixed on the inside of plastic boxes and $40 \mathrm{~mL}$ of water added. The boxes were closed and kept in an aging chamber for $72 \mathrm{~h}$ at $45^{\circ} \mathrm{C}$, according to Marcos-Filho (2005). After this period, the seeds were germinated at $25{ }^{\circ} \mathrm{C}$ and on the fourth day normal seedlings counting was carried out. The cold tolerance test was conducted using four replications of 50 seeds each. Briefly seeds where placed between sheets of "germitest" paper, moistened with distilled water and kept in cold chamber at $5{ }^{\circ} \mathrm{C}$ during seven days, and after this period, seeds were germinated and the normal seedlings evaluated according to Brasil (2009).

The total phosphorus, phytate, inorganic phosphorus, starch, soluble sugars, total protein and soluble protein were also evaluated. The total phosphorus content was quantified by the method proposed by Tedesco et al. (1995) and results were expressed in mg.g ${ }^{-1}$ of total phosphorus per seed dry weight. Total protein content was determined by an official method (AOAC, 1995), and results were expressed in mg.g${ }^{1}$ of total protein per seed dry weight. Phytate content was determined as described by Latta and Eskin (1980), which is based on the formation of an iron-sulfosalicylic acid compound of dark blue staining (Wade reagent). Readings were taken in a spectrophotometer (Marte Científica - Spectro $800 \mathrm{~S})$ at $500 \mathrm{~nm}$. The results were expressed in mg.g $\mathrm{g}^{-1}$ of phytate per seeds dry weight. The inorganic phosphorus content was determined using $0.100 \mathrm{~g}$ of dried ground seeds. The sample was extracted twice, for two minutes, with $4 \mathrm{~mL}$ of $12.5 \%$ trichloroacetic acid (w/v) in $0.025 \mathrm{M} \mathrm{MgCl}_{2}$ in a cold mortar. Each extract was centrifuged at $10,000 \mathrm{~g}_{\mathrm{n}}$ for $10 \mathrm{~min}$ and filtered through Whatman number 1 filter paper 
(Raboy and Dickinson, 1984). The filtered extracts were combined, diluted to $12.5 \mathrm{~mL}$ and inorganic phosphorus was determined colorimetrically, according to Chen et al. (1956). Results were expressed in $\mu \mathrm{g} . \mathrm{g}^{-1}$ of inorganic phosphorus per seeds dry weight.

Soluble sugar was analyzed using the method of Clegg (1956). The sample was extracted twice. A $0.250 \mathrm{~g}$ of dried and ground seeds were added $25 \mathrm{~mL} 80 \%$ ethanol and incubating for $7 \mathrm{~min}$ at $60^{\circ} \mathrm{C}$. After sample was centrifuged for $15 \mathrm{~min}$ at 7000 $\mathrm{g}_{\mathrm{n}}$ and the supernatant was stored. The sample was mixed with sulfuric acid and the anthrone reagent and then boiled until the reaction was completed. The solution was then allowed to cool and its absorbance was measured at $620 \mathrm{~nm}$. The results were expressed in mg.g $\mathrm{g}^{-1}$ of soluble sugar per seeds dry weight. For starch determination, after sugar extraction, each of the sample pellets were dried, resuspended in $20 \mathrm{~mL} \mathrm{H}_{2} \mathrm{SO}_{4} 0.2 \mathrm{~N}$ and boiled for 2 hours. Supernandant were react with anthrone reagent according Clegg (1956), and reading in a spectrophotometer (Marte Científica - Spectro 800S) at $620 \mathrm{~nm}$. The results were multiplied by 0.9 (glucose conversion factor to starch) and were expressed in mg.g $\mathrm{g}^{-1}$ of starch per seeds dry weight. For soluble protein, samples of $0.5 \mathrm{~g}$ were ground in liquid nitrogen, homogenized within $10 \mathrm{mM}$ potassium phosphate buffer ( $\mathrm{pH} 7.5$ ) containing $1 \mathrm{mM}$ of Ethylenediamine tetra acetic acid (EDTA), $3 \mathrm{mM}$ dithiothreitol (DTT) and 4\% polyvinyl polypyrrolidone (PVPP), as described by Azevedo et al. (1998) and Garcia et al. (2006). The homogenate was centrifuged at $9000 \mathrm{~g}_{\mathrm{n}}$ for 30 minutes and used for protein determination according to the Bradford method (1976). The results were expressed in mg. $\mathrm{g}^{-1}$ of soluble protein per seeds fresh weight.

Statistical analyzes were implemented in R software ( $R$ Core Team, 2016), version 3.3.1. All statistical analyses were applied using the same software and data represented as mean \pm standard deviation of four replicates $(\mathrm{n}=4)$ for physiological variables and three replicates $(\mathrm{n}=3)$ for a biochemical attributes. Scott-Knott test was applied as mean comparison test where statistical differences were found $(p<0.005)$ by analysis of variance (ANOVA). Principal component analysis (PCA) and hierarchical cluster analysis (HCA) was used to data set dimensionality reduction, find the relationship between genotypes and the main variables that contributed to sample similarity. Partial Least Squares Regression (PLS-R) was also applied with the main goal of identifying the biochemical parameters that most influenced physiological parameters.

\section{Results and Discussion}

Analysis of variance (ANOVA) of biochemical and physiological quality attributes of the inbred lines and hybrids indicated that there are significant differences (Figures 1, 2 and 3). The inbred lines CRI (1) and HIB1 (4) were superior in the germination test, with $93 \%$ and $99 \%$ of germination, respectively (Figure 1a). The VPA1 (2) inbred line presented higher vigor (71\%) in accelerated aging, while, VPA2 (3) and HIB2 (5) were more sensible to accelerated aging, presenting $31 \%$ and $4 \%$ of germination, respectively (Figure $1 b$ ). The HIB1 inbred line, showed greater vigor by the cold test, with a germination of $91 \%$ (Figure 1c). Hybrid $1 \times 3$ had the highest percentage of normal seedlings in germination test (98\%) (Figure 2a) and vigor demonstrated by accelerated aging test (Figure $2 \mathrm{~b}$ ) and cold test (Figure $2 \mathrm{c}$ ), with $88 \%$ and $91 \%$, respectively. Hybrid 1 x 4 and HIB1 behave similarly

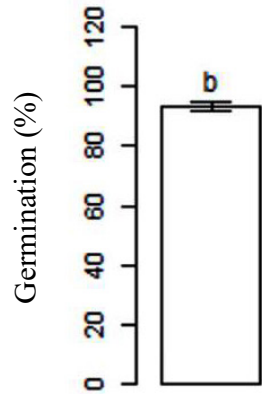

CRI

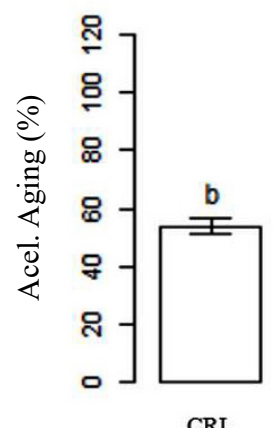

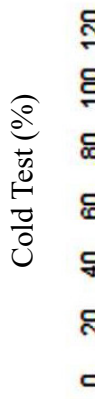

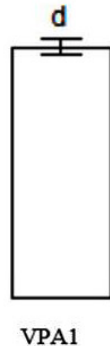

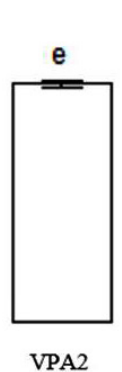

(a)

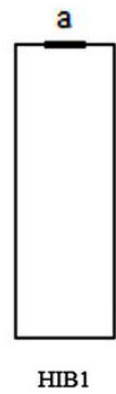

HIB2

(b)
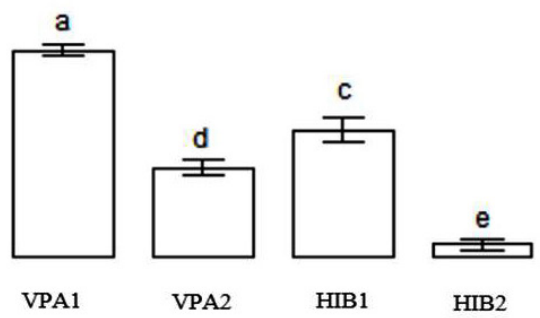

(c)

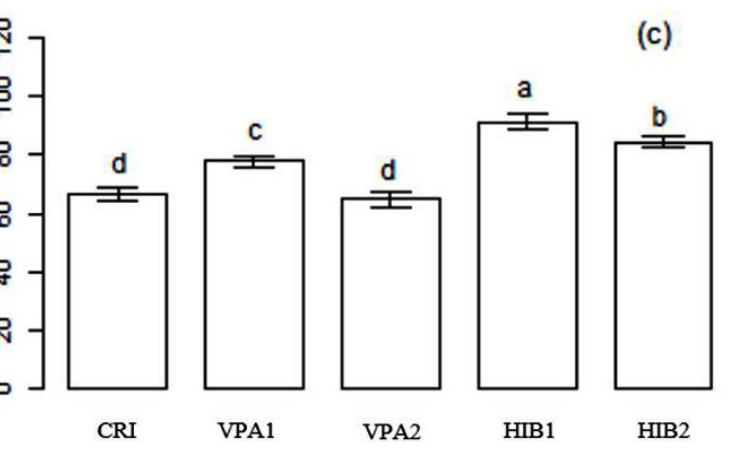

Figure 1. Means for germination (a), vigor by Accelerated Aging test (b) and vigor by cold test (c) of five inbred lines of maize seeds. The means were separated by Skott-Knott test at $5 \%$ probability and vertical bars indicate \pm standard deviation for $\mathrm{n}=4$ replications. 

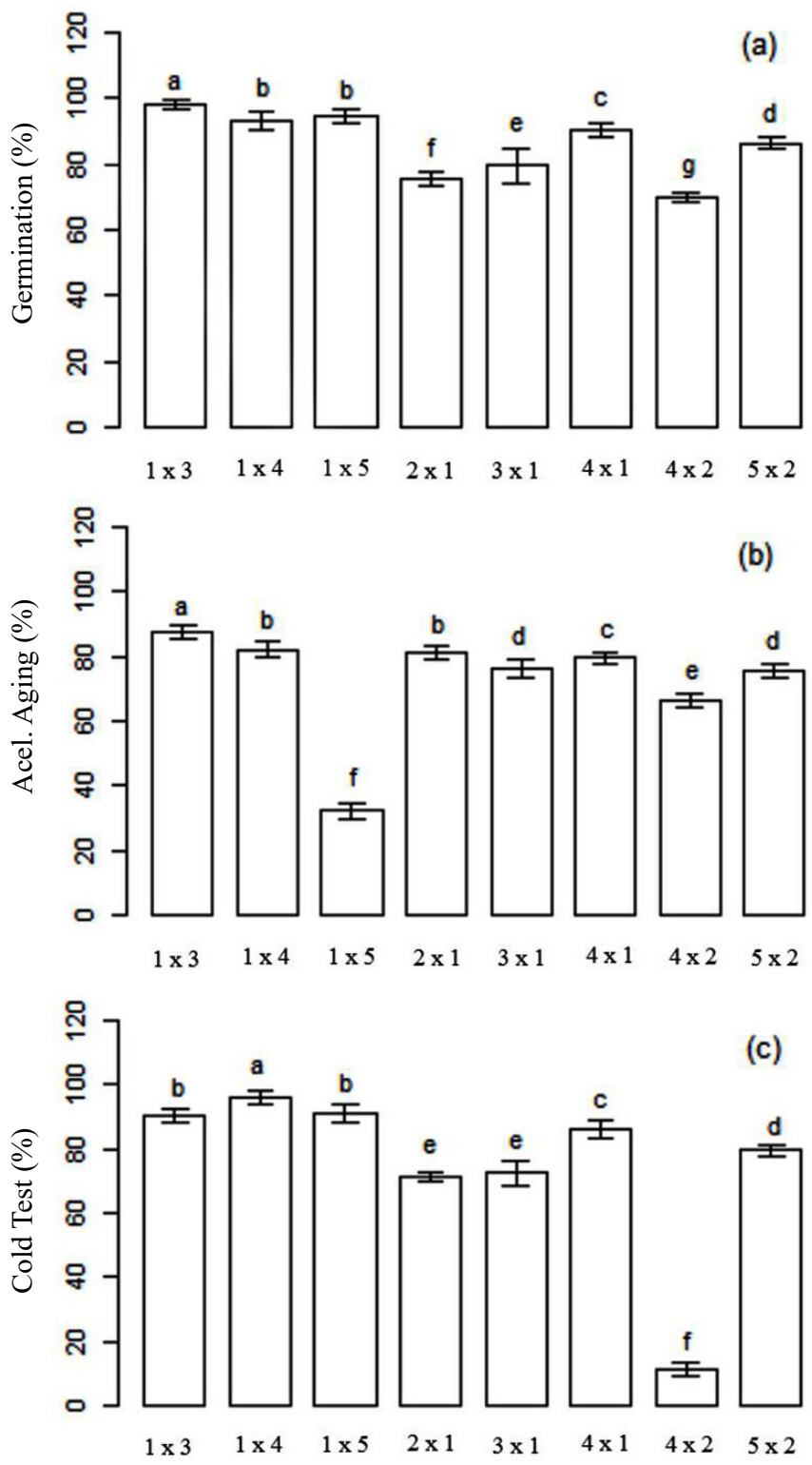

Figure 2. Means for germination (a), vigor by Accelerated Aging test (b) and vigor by cold test (c) of eight maize hybrids. The means were separated by Skott-Knott test at $5 \%$ probability and vertical bars indicate \pm standard deviation for $\mathrm{n}=4$ replications.

regarding germination and vigor by cold test (Figure 2c).

Observing the hybrid $1 \times 3$, it is possible to verify that the inbred line CRI, used as a male parent, has obtained $93 \%$ for germination, $54 \%$ of vigor by accelerated aging test and $67 \%$ by cold test (Figure 1). The inbred line VPA2, used as a female parent, obtained $80 \%$ of germination, $31 \%$ of vigor by accelerated aging test and $65 \%$ by cold test (Figure 1). This parents (CRI and VPA2), are not the best inbred lines, however, their combination was effective in obtaining seeds with better physiological quality. This was possible because of hybrid vigour or heterosis. In this study, only three combinations presented positive heterosis for the germination test, 1 x 3 (13.4\% of heterosis), 1 x $5(3.9 \%)$ and $5 \times 2(0.14 \%$ of heterosis). This result, as well as other studies, shows there is heterosis for germination. Nerling et al. (2013), when working with maize, obtained heterosis estimated that vary from $-8.16 \%$ to $+5.32 \%$ for germination test. However, it is different from results obtained by Reis et al. (2011), who observed a higher heterosis in the evaluation of 14 sweet corn genotypes, with variation of $+4,39 \%$ and $+15.62 \%$. The results presented in this study indicate the possibility of obtaining hybrid seeds with excellent physiological quality. Among the vigor tests, accelerated aging presented higher estimates for heterosis. The heterosis variation range, for the accelerated aging test, was from $+10.7 \%$ to $+106.8 \%$. It was possible to observe the germination of hybrid seeds, within the test conditions, was higher than their parental, indicating heterosis effect. The heterosis effect, as also observed by Nerling et al. (2013) and Prazeres and Coelho (2016).

The greater sensitivity observed in VPA2 and HIB2 inbred line in accelerated aging test, may be associated with lower levels of soluble sugars present in seeds (Figure 3d). A significant and positive correlation (0.92) between the soluble sugar content and vigor in accelerated aging in inbred lines was found (Figure 4a). The results of correlation between soluble sugar and vigor by accelerated aging test, suggest that higher initial content of soluble sugar contributes to higher vigor of seeds for VPA1 inbred line. Santos et al. (2017) observed the ratio between the sum of oligosaccharides and the sum of the monosaccharide reducing sugars, presented a positive correlation with the accelerated ageing, cold test and seedling emergence in the field tests in maize. This result indicate that seeds with a higher initial content of soluble sugars could overcome the stress condition. The soluble sugars are substrate for enzymes involved in the respiratory process, such as glucose-6-phosphate dehydrogenase. This enzyme operates in the alternative pentose phosphate pathway and is responsible for maintaining an adequate level of NADPH in cells, and malate dehydrogenase, which catalyzes the conversion of malate to oxaloacetate, having an important role in the Krebs cycle. In addition, glucose-6-phosphate dehydrogenase, participates in malate movement through the mitochondrial membrane in other cellular compartments (Tunes et al., 2011). In wheat seedlings that low concentration of glucose enhance the activity of antioxidant enzymes, such as peroxidase, catalase and superoxide dismutase (Hu et al., 2012). Sugars, such as sucrose, fructose and trehalose function as osmoprotectants in regulating the osmotic adjustment, provide membrane 

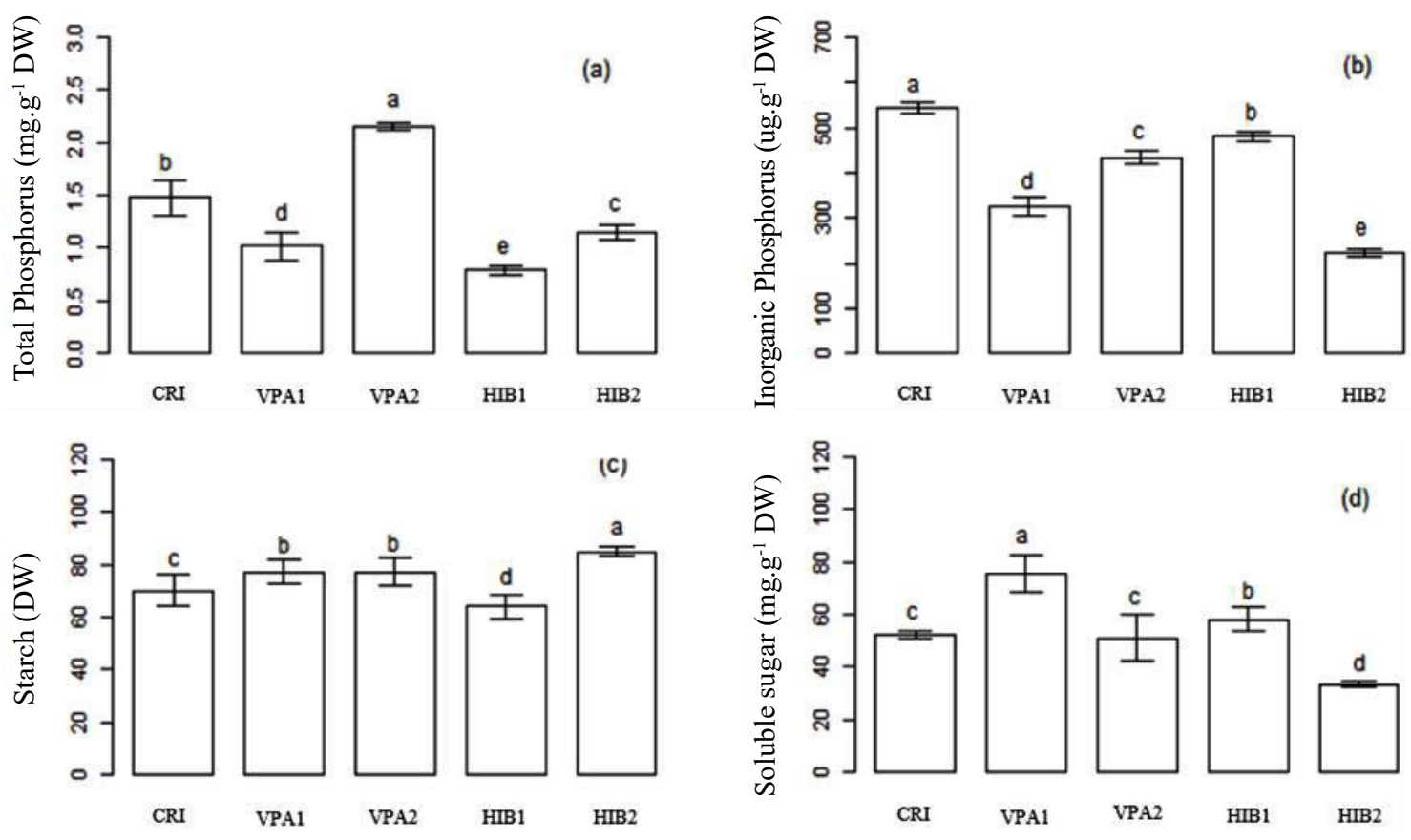

(d)
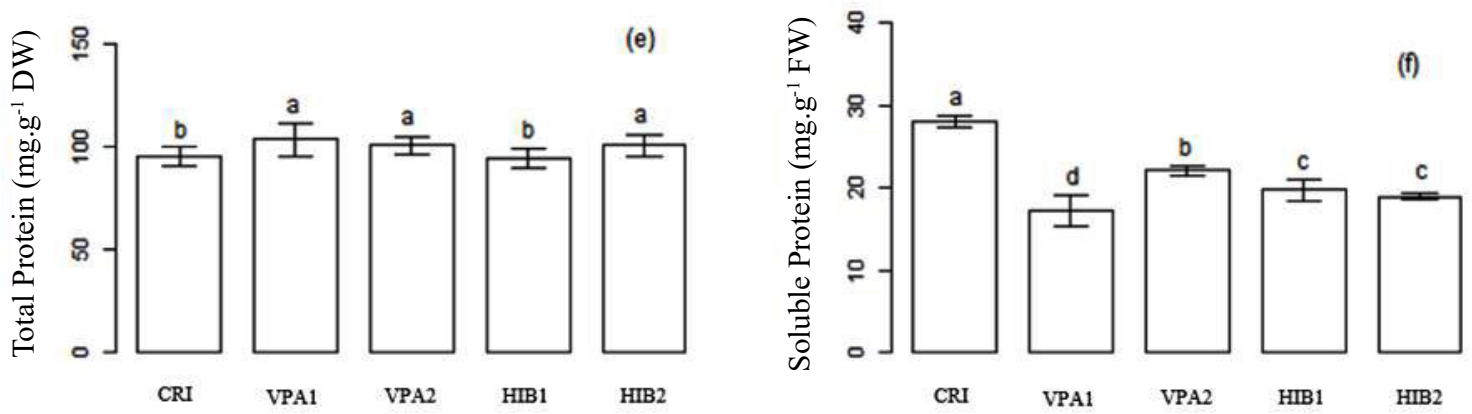

Figure 3. Means for total phosphorus content (a), inorganic phosphorus (b), starch (c), soluble sugar (d), total protein (e) and soluble protein content (f) of five inbred lines of maize seeds. The means were separated by Skott-Knott test at 5\% probability, and vertical bars indicate \pm standard deviation for $n=3$ replications.

protection and scavenge toxic ROS against various kind of stresses (Singh et al., 2015; Keunen et al., 2013). The nonreducing sugar sucrose, in conjunction with raffinose and stachyose, is thought to be important in the stabilization of the membrane system and in the protection of proteins in dehydrated seeds (Singh et al., 2015).

The soluble protein content was negatively correlated with the vigor for cold test (-0.63) (Figure 4a). This result suggests that the initial protein content in soluble form (Figure 3f), does not bring advantages when the seeds are submitted to conditions of stress by cold, for example. Low temperatures induce peroxidation of the membrane lipids, and the production of reactive oxygen species, that require a repair system to fight against free radicals in an efficient manner. A negative correlation between the total protein, total phosphorus, phytate and starch with physiological response of seeds also was found, and a negative correlation between germination and starch content $(-0.63)$ and the total phosphorus content (-0.65) (Figure 4b). Similar results were found by Santos et al. (2017), according these authors total protein and starch content are not correlated with vigour in maize seeds. Delgado et al., (2015), showing that the initial content of the reserve components was not the determining factor for the maintenance of the vigor in soybean seed. The results suggest that the germination and vigor may be associated with an efficient metabolism of hydrolysis and mobilization of reserves during the germination and not necessarily associated with a higher initial content of compounds as starch and phosphorus.

For better understanding the relationship between the biochemical components and the physiological response, that have not been identified in the correlation analysis, to 
determine the influence of each variable, to discriminate maize inbred lines for establish divergent groups to define strategy of genetic improvement, principal component analysis (PCA) was applied (Figure 5). Han et al. (2017) used PCA, to reveal distinct dynamic changes in metabolites between the embryo and endosperm during wheat germination.

The total variance explained by the two principal components was $68.9 \%$, being $38.3 \%$ and $30.6 \%$ for component 1 (PC1) and 2 (PC2), respectively (Figure 5). According Varmuza and Filzmoser (2009), if in a score plot, using the first two PCs, more than about $70 \%$ of the total variance is preserved, the scatter plot gives a good picture of the high-
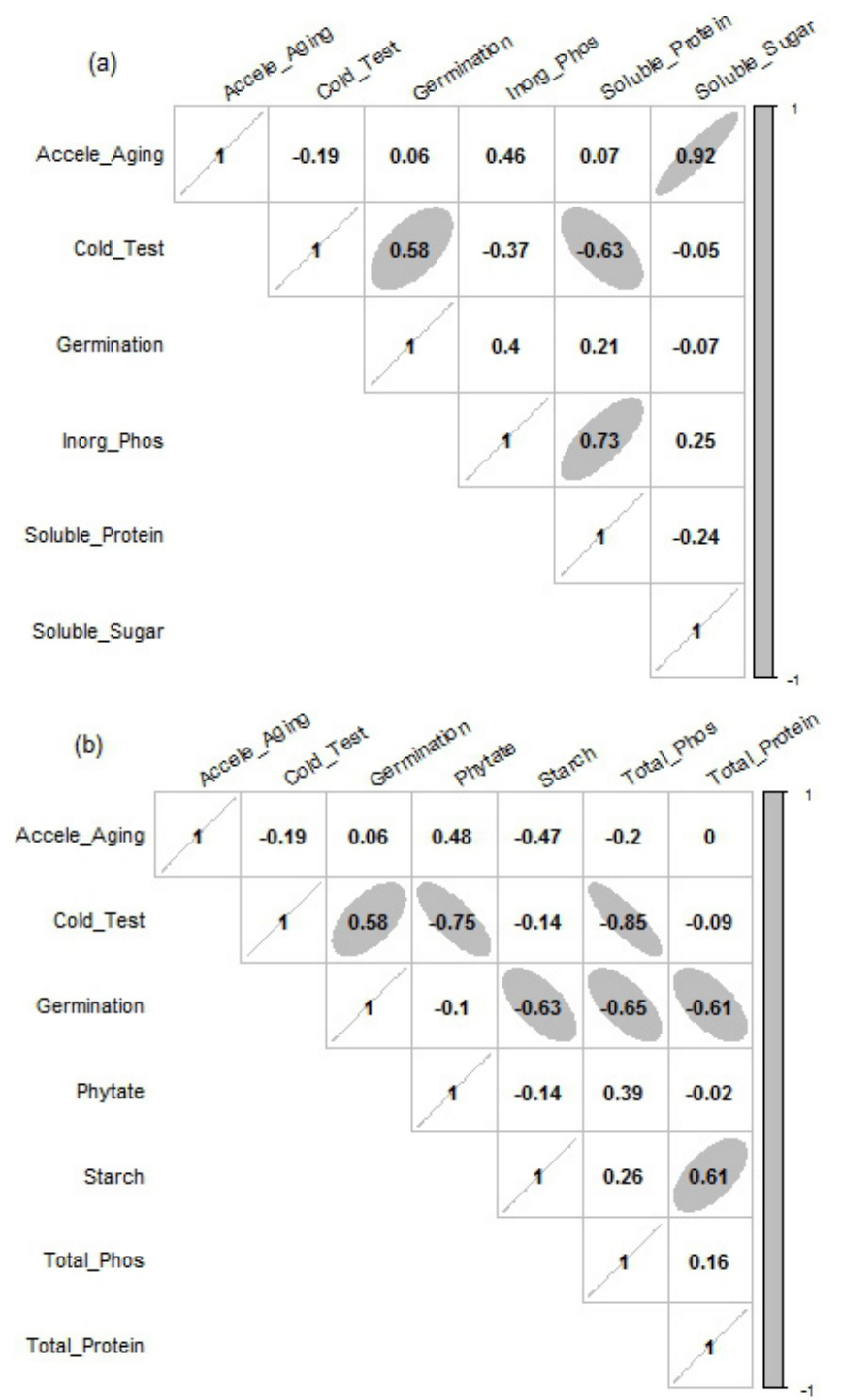

Figure 4. Correlation matrix of soluble (a) and forms of storage (b) of biochemical components and physiological data of five inbred lines of maize seeds. Highlighted values in this figure represent significant at $5 \%$ probability. dimensional data structure. The loading values showed that HIB1 inbred line grouped in $\mathrm{PC} 1+/ \mathrm{PC} 2+$ according to their germination and vigor by cold test. In PC1+/PC2-, VPA1 and HIB2 inbred line, grouped according to their starch content. In PC1-/PC2-, VPA2 inbred line grouped according to their total protein content, total phosphorus and soluble sugar contend. CRI inbred line grouped in PC1-/PC2+ according to their soluble protein content, inorganic phosphorus, phytate and accelerated aging.

The loadings plots indicated those parameters that contributed to discrimination of the objects described in the scores plot. Quantitative traits phytate, cold test, soluble protein and inorganic phosphorus were the most important for explaining the variation in the PC1. Germination, starch and total protein were the most important for determining the variation in PC2. PCA identified traits which contributed most to the variation of the analyzed genotypes and can serve as a useful tool for facilitating the selection of characteristics associated with seed quality in maize breeding.

The inbred lines were separated according different biochemical components and it is not clear what component is more important for all inbred lines. The PCA analysis indicates that the sample VPA1, VPA2 and HIB2 were influenced by biochemical components, such as starch, total protein and total phosphorus (Figure 5). Thus, in a breeding program these inbred lines can used to improve starch, total protein

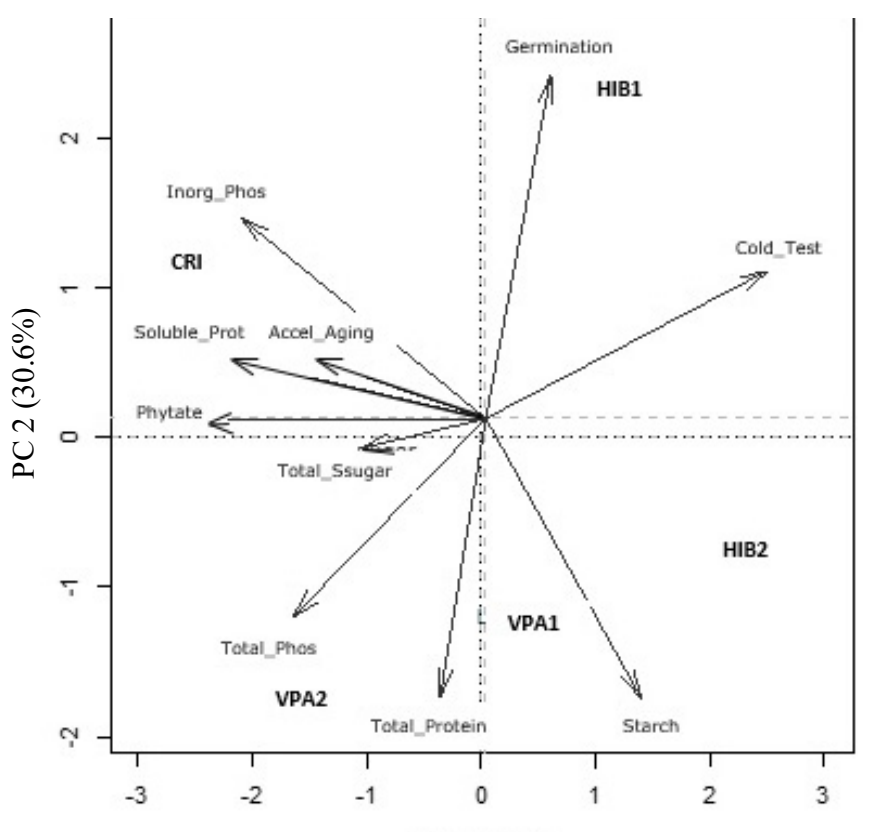

PC $1(38.3 \%)$

Figure 5. Scores of the first and second Principal Component (PCA) for biochemical composition and physiological response in five inbred lines of maize seeds. 
and total phosphorus in seed biochemical composition.

Cluster heatmap (HCA) of all data set (biochemical composition and physiological quality parameters) and maize genotypes (hybrids, inbred lines).

Hierarchical clustering is an easy and intuitive method to mathematically define the similarity between two objects based on the Euclidean distance (Uarrota et al., 2014). Cluster heatmap approach was also applied to all data set (biochemical composition and physiological quality parameters) and maize genotypes (hybrids and inbred lines). According to the cluster analysis six groups of genotypes were identified (Figure 6). The group one is formed by $1 \times 5,4 \times 1$ and HIB 1 genotypes, the group two by $2 \times 1,5 \times 2$ and VPA2, group three by CRI inbred line. Group four by $1 \times 4,4 \times 2$ and VPA1, group five by $1 \times 3$ hybrid and group six is formed by HIB 2 inbred line and $3 \times 1$ hybrid. The identification of groups is important to the choice of the parents used in breeding programs. According Santos et al. (2012), genotypes from the same group are genetically similar and their combinations may cause inferior variability when compared with the other groups. The inbred lines in distant groups, is indicative of being genetic divergence and can be considered promising in artificial crosses. Moreover, the divergence and genetic relations studies regarding physiological quality and biochemical composition support the selection strategies, aiming at the quality of seeds.

The cluster heatmap revealed that the inorganic phosphorus content was the variable that most contributed to the groups (Figure 6), while total phosphorus content have smaller influence on the samples. Thus, the forms of phosphorus available, as phytate or inorganic phosphorus, are important parameters in the characterization and identification of differences in performance in the sample, compared to the total phosphorus content of the seeds. Total protein content was important for the differentiation of VPA1, VPA2 and HIB2 in relation CRI and HIB1 inbred lines. Starch content, cold tolerance and germination also influenced HIB2, indicating that these parameters can be used to genotype characterization.

Although the inorganic phosphorus content is an important parameter for differentiating samples, the association of this component with the physiological response could not be identified. Thus, Partial Least Squares Regression (PLS-R) was applied to the data in other to verify if there is some degree of association between biochemical components and physiological quality in seeds, moreover, to verify the existence of other relations of cause and effect involving biochemical and physiological response components in the inbred lines.

According to the PLS-R, the soluble sugar and inorganic phosphorus content were the variable that most influenced the vigor by the accelerated aging test (Figure 7). The relationship between the soluble sugar content and accelerated aging has been identified previously by correlation analysis (Figure 4a), however, the direct influence of the inorganic phosphorus in the response of accelerated aging had not been previously identified. This component is essential for the synthesis of antioxidant enzyme systems, operating in the signaling and signal transduction (Raboy, 2009), important in stress conditions that require activation of a fast and efficient mechanism to combat the deterioration. Moreover, the inorganic phosphorus is associated with the starch hydrolysis, generating sugars that are used by the metabolism during germination by antioxidant enzymes in a stress condition. The analysis also indicates that the starch content and vigor by accelerated aging showed opposing relationship, suggesting that the larger initial content of starch cause a smaller vigor in accelerated aging. However, studies that observe the association between previously stored starch hydrolysis and the reserves mobilization during accelerated aging are needed to confirm this hypothesis. The PLS-R showed clearly the relationship between the biochemical composition and physiological response in this study.

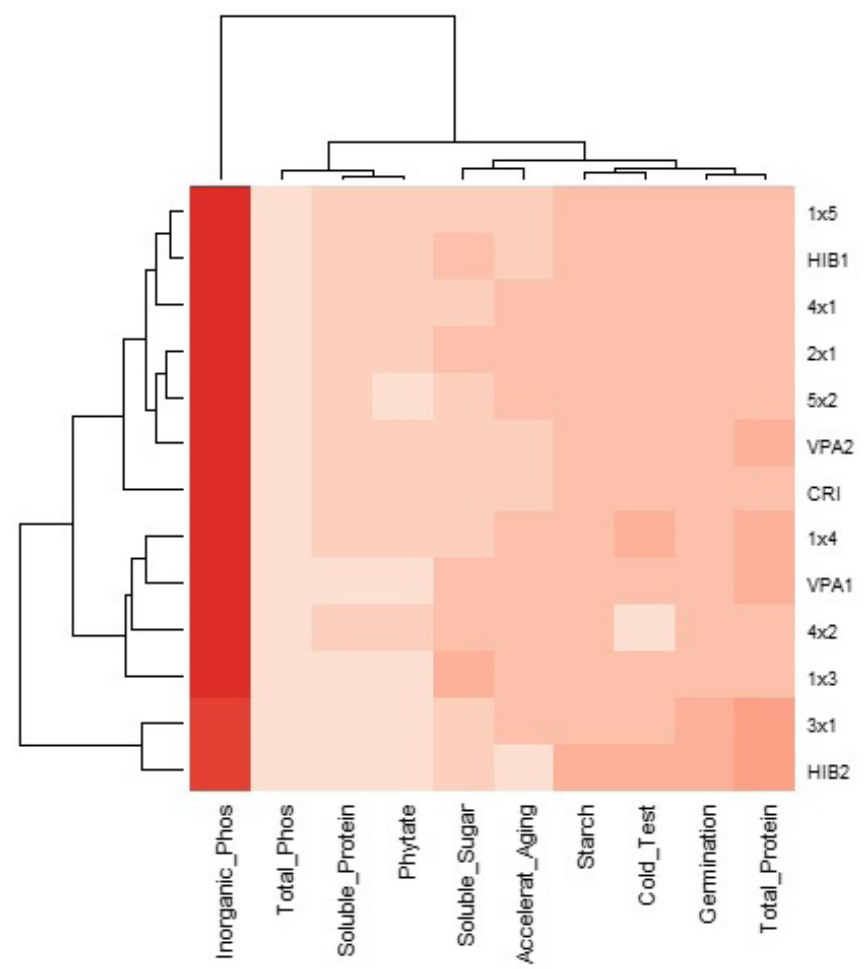

Figure 6. Cluster heatmap (HCA) of all data set (biochemical composition and physiological quality parameters) and maize genotypes (hybrids, inbred lines), with cophenetic correlation coefficient of $88 \%$. 


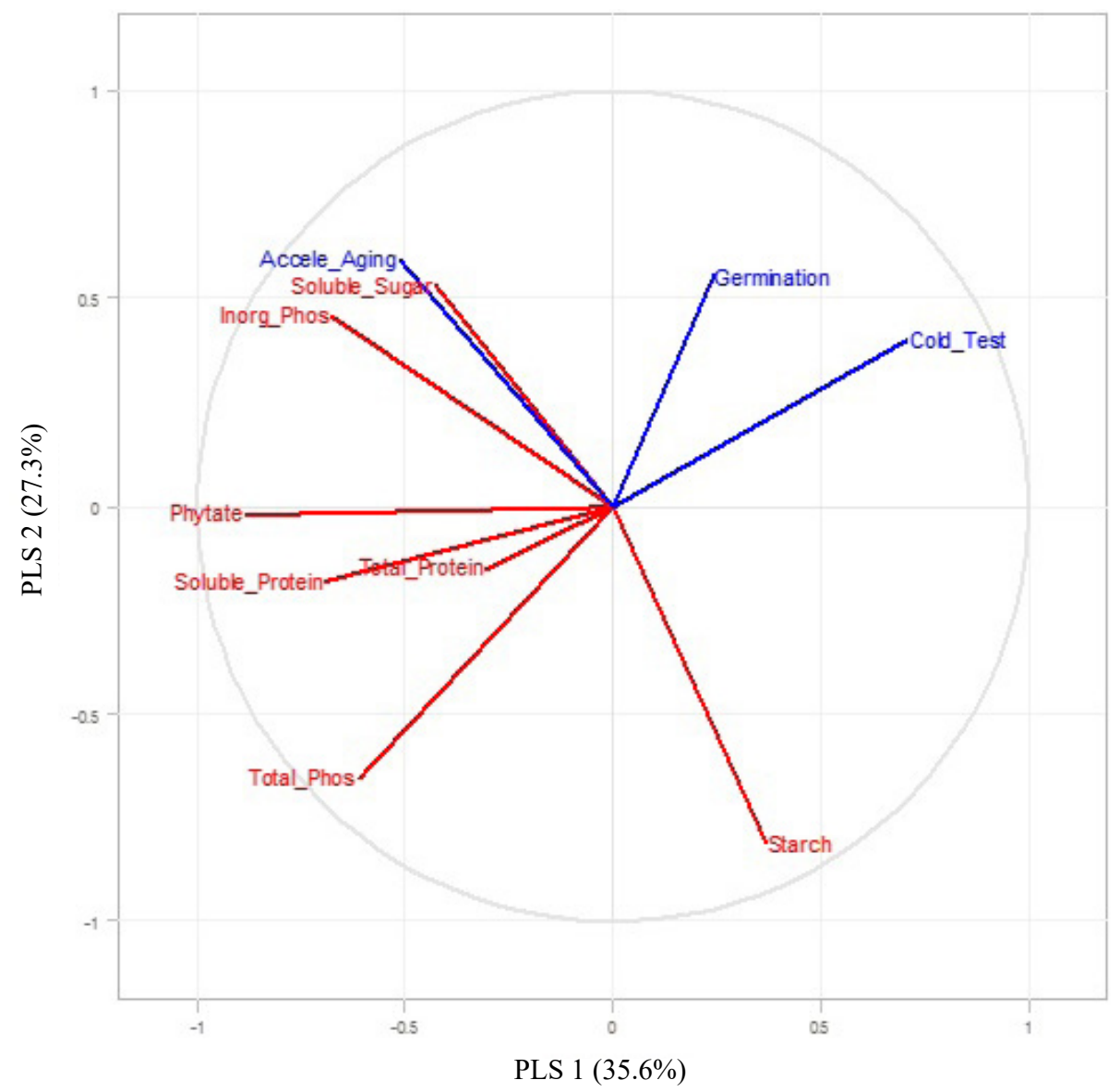

Figure 7. Scores of PLS-R component of association between biochemical composition and physiological response in five inbred lines of maize seeds.

\section{Conclusions}

There are genetic divergence among the maize inbred lines, being promising to obtain seeds of better biochemical composition and higher physiological quality. The physiological quality of seed was positively influenced by higher initial content of soluble sugars and inorganic phosphorus.

\section{References}

AOAC (Association of Official Analytical Chemists). Vitamins and other nutrients. In: AOAC. Official methods of analysis. 16. ed. Vol. II. AOAC International: Arlington, cap. 45, p. 58-61, 1995.

AZEVEDO, R.A.; ALAS, R.M.; SMITH, R.J.; LEA, P.J. Response of antioxidant enzymes to transfer from elevated carbon dioxide to air and ozone fumigation, in the leaves and roots of wild-type and a catalasedeficient mutant of barley. Physiologia Plantarum, v. 104, p.280-292, 1998. http://dx.doi.org/10.1034/j.1399-3054.1998.1040217.x

BEWLEY, J.D.; BRADFORD, K.; HILHORST, H.; NONOGAKI, H. Seeds, physiology of development, germination and dormancy. 3 . ed. New York: Springer, 2013. 392p.
BERNAL-LUGO, I.; LEOPOLD, A. C. Seed stability during storage: Raffinose content and seed glassy state. Seed Science Research, v.5, p.75-80, 1995. http://dx.doi.org/10.1017/s0960258500002646.

BRADFORD, M.M. A rapid and sensitive method for the quantitation of microgram quantities of protein utilizing the principle of proteindye binding. Analytical Biochemistry, v. 72, p. 248-254, 1976. http:// dx.doi.org/10.1016/0003-2697(76)90527-3.

BRASIL. Ministério da Agricultura, Pecuária e Abastecimento. Regras para análise de sementes. Ministério da Agricultura, Pecuária e Abastecimento. Secretaria de Defesa Agropecuária. Brasília: MAPA/ACS, 2009. 395p. <http://www.agricultura.gov.br/ arq editor/file/2946 regras analise sementes.pdf $>$.

CHEN, P.S.; TORIBARA, T.Y.; WARNER, H. Microdetermination of Phosphorus. Analytical Chemistry, v. 28, p. 1756-1758, 1956. http://dx.doi.org/10.1021/ac60119a033.

CLEGG, K. M. The application of the anthrone reagent to the estimation of starch in cereals. Journal of the Science of Food and Agriculture, v.7, p.40-44, 1956. http://dx.doi.org/10.1002/ jsfa.2740070108. 
DELGADO, C.M.L.; COELHO, C.M.M.; BUBA, G.P. Mobilization of reserves and vigor of soybean seeds under desiccation with glufosinate ammonium. Journal of Seed Science, v.37, p.154-161, 2015.http://dx.doi.org/10.1590/2317-1545v37n2148445

GARCIA, J.S.; GRATÃO, P.L.; AZEVEDO, R.A.; ARRUDA, M.A. Metal contamination effects on sunflower (Helianthus annuus L.) growth and protein expression in leaves during development. Journal of Agricultural and Food Chemistry, v.54, p.8623-8630, 2006. http:// dx.doi.org/10.1021/jf0615931.

HAN, C.; ZHEN, S.; ZHU, G.; BIAN, Y.; YAN, Y. Comparative metabolome analysis of wheat embryo and endosperm reveals the dynamic changes of metabolites during seed germination. Plant Physiology and Biochemistry, v.115, p.320-327, 2017. http://dx.doi. org/10.1016/j.plaphy.2017.04.013

HE, H.; VIDIGAL, D. V.; SNOEK, L. B.; SCHNABEL, S.; NIJVEEN, H.; HILHORST, H.; BENTSINK, L. Interaction between parental environment and genotype affects plant and seed performance in Arabidopsis. Journal of Experimental Botany, v. 65, p. 6603-6615, 2014. http://dx.doi.org/10.1093/jxb/eru378.

HENNING, F.A.; MERTZ, L.M.; JACOB JUNIOR, E.A.; MACHADO, R.D.; FISS, G.; ZIMMER, P.D. Composição química e mobilização de reservas em sementes de soja de alto e baixo vigor. Bragantia, v.69, n.3, p.727-734, 2010. http://www.scielo.br/pdf/ brag/v69n3/26.pdf

HU, M.; SHI, Z.; ZHANG, Z.; ZHANG, Y.; LI, H. Effects of exogenous glucose on seed germination and antioxidant capacity in wheat seedlings under salt stress. Plant Growth Regulation, v. 68, p. 177-188, 2012. http://dx.doi.org/10.1007/s10725-012-9705-3.

KEUNEN, E.; PESHEV, D.; VANGRONSVELD, J.; ENDE,W.; CUYPERS, A. Plant sugars are crucial players in the oxidative challenge during abiotic stress: extending the traditional concept. Plant Cell \& Environment, v. 36, p. 1242-1255, 2013. http://dx.doi. org/10.1111/pce.12061

KIM, H.T.; CHOI, U.; RYU, H.S.; LEE, S.J.; KWON, O. Mobilization of storage proteins in soybean seed (Glycine $\max \mathrm{L}$.) during germination and seedling growth. Biochimica et Biophysica Acta, v.1814, p.1178-1187, 2011. http://dx.doi.org/10.1016/j. bbapap.2011.05.004

LATTA, M.; ESKIN, M. A simple and rapid colorimetric method for phytate determination. Journal of Agricultural and Food Chemistry, v. 28, p. 1313-1315, 1980. http://dx.doi.org/10.1021/jf60232a049.

MARCOS-FILHO, J. Fisiologia de sementes de plantas cultivadas. Piracicaba: FEALQ, 2005. 495p.

NERLING, D.; COELHO, C. M. M.; NODARI, R.O. Genetic diversity for physiological quality of seeds from corn (Zea mays L.) intervarietal crossbreeds. Journal of Seed Science, v. 35, p. 449-456, 2013. http://dx.doi.org/10.1590/s2317-15372013000400006

PRAZERES, C. S.; COELHO, C.M.M. Heterose para qualidade fisiológica de sementes na obtenção de hibridos de milho. Revista Brasileira de Milho e Sorgo, v.15, n.1, p. 124-133, 2016. http://rbms. cnpms.embrapa.br/index.php/ojs/article/view/559
R CORE TEAM. R: A language and environment for statistical computing. R Foundation for Statistical Computing, Vienna, Austria, 2016. https://www.R-project.org/.

RABOY, V. Approaches and challenges to engineering seed phytate and total phosphorus. Plant Science, v. 177, p. 281-296, 2009. http:// dx.doi.org/10.1016/j.plantsci.2009.06.012.

RABOY, V.; DICKINSON, D. B. Effect of phosphorus and zinc nutrition on soybean seed phytic acid and zinc. Plant Physiology, v. 75, p. 1094-1098, 1984. http://dx.doi.org/10.1104/pp.75.4.1094.

RAJJOU, L.; DUVAL, M.; GALLARDO, K.; CATUSSE, J.; JOB, C.; JOB, D. Seed Germination and Vigor. Annual Review of Plant Biology, v. 63, p. 507-533, 2012. http://dx.doi.org/10.1146/annurevarplant-042811-105550.

REIS, L.S.; PEREIRA, M.G.; SILVA, R.F.; MEIRELES, R.C. Efeito da heterose na qualidade de sementes de milho doce. Revista Brasileira de Sementes, v.33, p.310-315, 2011. http://www.scielo.br/ pdf/rbs/v33n2/13.pdf

SANTOS, E.R.; BARROS, H.B.; CAAPONE, A.; MELO, A.V.; CELLA, A.J.S.; SANTOS, W.R. Divergência genética entre genótipos de soja com base na qualidade de sementes. Revista Brasileira de Ciências Agrárias - Brazilian Journal of Agricultural Sciences, v. 7, p. 247-254, 2012. http://dx.doi.org/10.5039/agraria.v7i2a1560.

SANTOS, J.; DIRK, L.; DOWNIE, A.B.; VIEIRA, R. Reciprocal effect of parental lines on the physiological potential and seed composition of corn hybrid seeds. Seed Science Research, p. 1-11, 2017. https://doi.org/10.1017/S0960258517000095.

SINGH, M.; KUMAR, J.; SINGH, S.; SINGH, V.; PRASAD, $\mathrm{S}$. Roles of osmoprotectants in improving salinity and drought tolerance in plants: a review. Reviews in Environmental Science and Bio/Technology, v. 14, p. 407-426. 2015. http://dx.doi.org/ $10.1007 \% 2$ Fs $11157-015-9372-8$

TEDESCO, M.J.; GIANELLO, C.; BISSANI, C.A.; BOHNEN, H.; VOLKWEISS, S.J. Análise de solo, plantas e outros materiais. 2. ed. Porto Alegre: UFRGS, 1995, 174p.

TUNES, L.M.; BADINELLI,P.G.; BARROS, C.S.A.; MENEGHELLO, G.E.; AMARANTE, L. Influência dos diferentes períodos de colheita na expressão de isoenzimas em sementes de cevada. Revista Ceres, v. 58, p. 178-184, 2011. http://dx.doi.org/10.1590/S0034-737X2011000200008.

UARROTA, V.G.; MORESCO, R.; COELHO, B.; NUNES, E.C.; PERUCH, L.A.M.; NEUBERT, E.O.; ROCHA, M.; MARASCHIN, M. Metabolomics combined with chemometric tools (PCA, HCA, PLSDA and SVM) for screening cassava (Manihot esculenta Crantz) roots during postharvest physiological deterioration. Food Chemistry, v. 161, p. 67-78, 2014. http://dx.doi.org/10.1016/j.foodchem.2014.03.110.

VARMUZA, K.; FILZMOSER, P. Introduction to Multivariate Statistical Analysis in Chemometrics. Boca Raton: CRC Press, 2009. 336p.

VENTURA,D.M.; MACOVEI,A.;CARBONERA,D.;BUTTAFAVA, A.; MONDONI, A.; ROSSI, G.; BALESTRAZZI, A. Understanding the molecular pathways associated with seed vigor. Plant Physiology and Biochemistry, v. 60, p. 196-206, 2012. http://dx.doi.org/10.1016/j. plaphy.2012.07.031. 